\title{
Obituary
}

\section{William fohn Brownlow Riddell, FRS, MD, ChB, FRFPS, DOMS}

W. J. B. Riddell, Emeritus Tennent Professor of Ophthalmology at the University of Glasgow, died suddenly on 18 February 1976 while on holiday in Austria. He was in his 78 th year.

Brought up in Glasgow where his father was visiting ophthalmic surgeon to the Eye Infirmary, he received his education at Glasgow Academy, and thereafter was commissioned in the Royal Naval Volunteeer Reserve, serving at sea as midshipman for the last year of the first world war. After demobilization he chose a medical career and graduated $\mathrm{MB}, \mathrm{ChB}$ at Glasgow University in 1923. In the very unsettled years after the war, he held a succession of junior posts and gradually became orientated towards ophthalmology, adding the qualifications DOMS London in 1928, and FRFPS Glasgow in 1936, until finally he went to the Royal London Ophthalmic Hospital to pursue his chosen specialty. He then returned to Glasgow as surgeon to the Ophthalmic Institute of Glasgow Royal Infirmary, and in 1940 he presented a thesis based on his research in human heredity which was receiving international recognition, and was awarded MD with high commendation.

In 194I he was appointed to the Tennent Chair of Ophthalmology at the University of Glasgow. The Tennent Institute, completed in 1936, had been designed with the dual purpose of providing university teaching and research facilities while also serving as the eye department of a large general hospital, the Western Infirmary. He had to defer his plans for research and staffing his new department owing to the exigencies of the second world war, but with characteristic foresight he began to assemble the nucleus of what proved to be an outstanding reference library. In addition to sustaining the needs of his hospital and private practices, he so organized his time as to allow regular visits to London where he served on the ophthalmic panel formed to advise the Ministry of Supply on the effects of chemical warfare agents on the eye. He also accepted the additional duty of Dean of the Faculty of Medicine for the University of Glasgow; in this capacity he visited North America in the immediate postwar period and was invited to lecture on his specialty at many university centres. The inception of the National Health Service in 1948 presented him with a role for his administrative ability which was ably demonstrated over a long period on the board of management of Glasgow Western Hospitals; he was also president for more than 20 years of the Mission to the Outdoor Blind for Glasgow and the West of Scotland. His many other offices included the presidency of the ophthalmological section of the Royal Society of Medicine, the vicepresidency of the Ophthalmological Society of the United Kingdom, and the vice-presidency of the Faculty of Ophthalmologists. He retired from the Chair after 23 years of distinguished service in 1964, relinquished his appointment as senior ophthalmic consultant to the Western Infirmary, and ceased all active practice.

Professor Riddell was scrupulous in all he undertook. A perfectionist in his own surgical technique, he set a high standard in his training of others and passed on his skills to many postgraduate students. He could express himself concisely and cogently, and was adept in selecting the most suitable form of illustration and presentation of a subject; his criticism of the work of others was always generous and helpful. An agile mind, his width of reading and ability to marshal and analyse facts rapidly, enabled him to make an incisive contribution to the discussion of many topics. He was a stimulating companion during his occasional leisure hours, whether watching cricket, strolling through a park, or browsing in a gallery or museum. Visitors were always made welcome at his home, and many in various parts of the world will carry with them the memory of the generous and warm hospitality they received on visiting Bill Riddell and his charming wife, Nan.

After retiring in 1964, he went to live in Aberdeen, where his family roots lay. This environment supplied an aura of university life which he found congenial, but was also becoming enfused with new cultural activities which served to occupy the interests of a nature always active. Survived by his wife, a son, and a daughter who is a consultant pathologist, he was an outstanding specialist of his generation.

\section{Sir Tudor Thomas, DSC, MD, FRCS, LLD}

Wales and ophthalmology have lost one of their great medical personalities in the death of Sir Tudor Thomas at the age of 82 .

He was born in Breconshire but spent most of his professional life in Cardiff where he was much esteemed by his colleagues and many friends.

His academic achievements were many, for as well as winning prizes as a student at Cardiff University and at the Middlesex Hospital, he gained most of the degrees possible to a graduate. Later he had an Honorary LLD conferred on him by Glasgow University. He served in the RAMC in the first world war and in 1921 was appointed ophthalmic surgeon to the Cardiff Royal Infirmary and United Cardiff Hospitals which he served for 37 years.

He sprang to fame in 1922 by becoming the pioneer 